\title{
CONSTITUTIONALITY OF THE PRORATIONING SCHEME IN ALBERTA
}

JOHN RATHWELL*

A host of legislation has accompanied the growth of the oil and gas industry in the province of Alberta. The nature of oil and gas, combined with the rule of capture, has been the prime inducement for this intervention by the legislature. Oil and gas, besides being fugacious in nature, are limited resources. Thus, if an owner of the mines and minerals wishes to recover the oil and gas below the surface, it is incumbent upon him to drill and produce as quickly as possible to prevent his oil from being drained by his neighbour. The result is a feverish race to recover the black gold from the earth's treasury. ${ }^{2}$ Memories of gas wells burning unrestrained on the distant horizon, of great pools of oil seeping into the ground, never to be recovered again, are still vividly fresh in the minds of people in oil-producing countries, and serve dramatically to remind them how harsh the consequences of this wild and frenzied pursuit of oil can be.

Yet, in a society nurtured on free enterprise principles, there was at first no awareness that things should be otherwise. However, in time it became manifestly clear that it was in the interests of society, and the industry as well, to bring an abrupt halt to the tragic waste of these vital resources. But as long as the rule of capture continued to dominate the scene, one could only look in vain to the oil industry for the necessary relief. It was therefore imperative that the government intrevene. In Canada, the problem was presented as to which government, Dominion or Provincial, possessed the authority under our constitution, the British North America Act, ${ }^{2}$ to undertake the task. The legislature of Alberta has proceeded on the basis that it has authority, and has passed numerous statutes which extensively regulate the oil industry. One of the most significant of these is The Oil and Gas Conservation Act. ${ }^{3}$ Pursuant to this Act, an oil pro-rationing scheme has been established which, as well as pro-rationing production among the producers in Alberta, limits the production of oil to market demand. ${ }^{*}$ It is the purpose of this paper to inquire whether the Legislature of Alberta actually does possess the constitutional authority which it has purported to exercise.

\section{NATURE OF THE PRORATIONING SCHEME}

It will be helpful to indicate generally the operation of the scheme. The Oil and Gas Conservation Board," constituted by the Oil and Gas Conservation Act, conducts hearings once each month, at which time purchasers of Alberta oil submit nominations which indicate the quantity of oil they are prepared to purchase in the forthcoming month. The total

- B.A.. LL.B., (Alta.), of the 1965 graduating class.

1 For a detailed and interesting account of this history see Max Ball, This Fascinating Oil Business.

2 (Imp.) 30 \& 31 Vict., c. 3.

3 (Alta.) 1957, c. 63.

4 For the purposes of this paper, the scheme as it now exists will be discussed. A modified scheme is scheduled to come into operation in the near future.

5 Hereinafter referred to as the "Board." 
of these nominations makes up at once the market demand and the allowable provincial production for the forthcoming month. The purpose and intent of the scheme are to give all producers a share of this demand; and, to that end, the Board assigns a production rate to each well within the province. ${ }^{\circ}$

In arriving at this rate, the Board takes into account what is known as the "Economic Allowance" and the "Maximum Permissive Rate" (M.P.R.). The M.P.R. is the rate at which a well may produce oil without either damage to the pool or waste of reservoir energy. After sufficient production experience is gained from an oil pool, it is possible to establish a "Maximum Efficiency Rate" (M.E.R.) for the pool, which is a maximum rate at which production may be taken consistent with sound economics and good reservior engineering practice. ${ }^{7}$

It was apparent that, if no well was ever permitted to produce beyond its M.P.R. or M.E.R., a number of wells would have to cease production, as it would not be economically feasible to produce at the M.P.R. rate. The Board, in an attempt to avert this result, has assigned to each well an economic allowance based on current costs of drilling and production and scaled to the depth of the well. An even more significant factor giving rise to the establishment of an economic allowance is the existence of a large excess of potential production over market demand. If production were restricted solely on the basis of an equal division of market demand amongst wells, then it is clear that, although a well might have a very high M.P.R., still the portion of market demand allocated to it might not justify continued operation of the well. The economic allowance was designed, in part, to obviate such a result.

In the distribution of the market demand, each well is permitted to produce its economic allowance. The total economic allowance of all the wells is then subtracted from the provincial allowable, and what remains is termed the residual demand. The residual demand is allowed to each well according to a formula which involves consideration of the M.P.R. ${ }^{8}$

\section{CONSTITUTIONAL PRINCIPLES}

Since the scheme regulates the production of oil of which only a small percentage is consumed in Alberta, the immediate reaction of constitutional theorists must be that it is an encroachment of Parliament's sovereign power over the "Regulation of Trade and Commerce," under s. 91 (2) of the British North America Act. For although that source of

6 Section 36 of The Oil and Gas Conservation Act reads as follows:

(1) The Board may, by general or special orders, restrict the amount of oil or gas or both that may be produced within the province

(a) by fixing a provincial allowable for crude oil, condensate and pentanes plus not exceeding the market demand as determined by the Board,

(b) by allocating the provincial allowable for crude oil, condensate and pentanes plus in a reasonable manner among the producing pools in the Province by fixing the amount of crude oil or condensate that may be produced from each fixing the amount of crude oil or condensate that may be produced from each pool, or of pentanes plus that may be produced from

(c) by distributing the portion of the provincial allowable allocated to a pool in an equitable manner among the wells in the pool, for the purpose of giving each well owner the opportunity of producing or receiving his just and equitable share of the oil in the pool.

T For a full account of the M.P.R. and M.E.R. see The General Functions of the Oil and Gas Conservation Board, Province of Alberta. A Submission to the Royal Commission on Energy under Chairmanship of Henry Borden. Esq.. Feb. 3, 1958 at 27.

8 In the near future it may be expected that the residual demand will be allocated according to a formula which places considerable emphasis on well reserves. 
authority has, in the minds of federalist enthusiasts, been severely emasculated in the hands of the Privy Council, it has always been recognized that it at least encompassed inter-provincial and foreign trade." However, it is submitted that, in the light of recent Supreme Court of Canada decisions, a critical analysis of the legislation may demand a different answer or, at the least, indicate that the problem does not admit of so easy a solution.

In those recent decisions, the Supreme Court, in an attempt to provide a workable solution to provincial-federal conflicts, has resorted to the well-known double aspect test. That test was enunciated as early as 1883 in Hodge v. Queen; ${ }^{10}$ but received a restricted application during the first part of the present century, ${ }^{11}$ only to receive a fresh breath of life in recent times." Its effect is that "subjects which in one aspect and for one purpose fall within s. 92, may in another aspect and for another purpose fall within s. 91."13 That is to say, it is essential to look to the real purpose and character of the legislation (its pith and substance ${ }^{14}$ ) to determine what matters the legislation in fact relates to, whether provincial or federal; for, although Parliament may have authority to pass certain legislation in exercise of a federal power, it may be that the provincial legislature can validly pass identical legislation in exercise of a provincial power. ${ }^{1 ;}$ In such circumstances, in the event of conflict between legislation passed by the two jurisdictions, federal legislation will prevail, by virtue of the concluding clause of section 91 of the B.N.A. Act. ${ }^{16}$

\section{PITH AND SUBSTANCE OF THE PRORATIONING SCHEME}

What, then, is the real purpose and object of the pro-rationing scheme? Is it, in fact, designed to promote conservation and the equitable sharing of oil between landowners, both of which are legitimate provincial interests; or is it in pith and susbtance the regulation of production of inter-provincial commerce in oil, clearly a federal matter? The constitutionality of the pro-rationing scheme must hinge on the answer to these questions.

It should be pointed out at the outset that it is not enough to look to the effect of the legislation. That effect is manifestly to regulate production of inter-provincial oil. We must look further, for the reason that in nearly all of the cases involving double aspect an identical result can be achieved by each of the legislators. Professor Smith says of the double aspect test: "This involves a classification of powers based on the

o Citizen's Insurance Company of Canada v. Parsons (1881), 7 App. Cas. 96; Lauson V. Interior Tree Fruit and Vegetable Committee of Direction, [1931] S.C.R. 357; Re The Farm Products Marketing Act, [1957] S.C.R. 198.

10 (1883), 9 App. Cas. 117.

11 A-G. (Canada) v. A-G. (Alberta), $|1916| 1$ A.C. 588.

12 There are several cases, which will be referred to later.

13 Ante, n. 10 , at 130 . 13 Ante, n. 10, at 130 .
it For the enunciation of the "pith and substance" rule see: A-G. (Canada) v. A-G.
(Ontario). $11898 \mid$ A.C. 700, 714, 715: Union Colliery Co. v. Bryden. $\mid 1899]$ A.C. 580, 587, 588; Board of Trustees of the Lethbridge Northern District v. I.O.F., [1940] A.C. 513, 529: A-G (Alberta) v. A-G. (Canada), |1943| A.C. 356, 370.

1.: It is unnecessary to employ the double aspect test unless it would be within the competence of both the provincial legislature and Parliament to pass the same legislation. Otherwise it would simply be a matter of determining whether in plth legislation. Otherwise it would simply be a matter of determining whether in pith
and substance the matter fell within one of the various enumerated heads in ss. 91 and 92. Here, we will proceed on the basis that Parliament does have the power to pass the same legislation. even though that is far from clear.

1i A-G. (Ontario) v. A-G. (Canada), |1896| A.C. 348. 
nature and purpose of their exercise rather than on the practical effect or operation thereof." 17 The important inquiry is what was the aspect and purpose of the legislation-in relation to what was it passed?

\section{Conservation}

The concept of conservation has in recent times taken on a broad connotation. ${ }^{18}$ Historically, it was restricted to the preservation of resources in a physical sense. Today, most students of conservation are agreed that the prevention of economic waste is of paramount importance. ${ }^{10}$ There can be no doubt that it is within provincial competence to prevent physical waste. ${ }^{20}$ Whether that is true of economic waste is an altogether different matter, which will be discussed at a later point in this paper. First we must determine the true purport of the pro-rationing legislation.

Insofar as the pro-rationing scheme limits production to the Maximum Permissive Rate, it is incontestable that its main purpose is to prevent physical waste; for, in limiting production to the M.P.R., it ensures that the total ultimate recovery will not be reduced by the premature waste of energy, whatever form that energy may take. This is known as underground waste. The early history of the oil and gas industry in the United States graphically illustrates that the M.P.R. was necessary to prevent surface and economic waste as well. ${ }^{21}$

During the early 1930's wells tended to spring up on the land of every landowner who thought he had oil. There was a race to recover as much oil as possible, to prevent drainage by neighbouring wells. Due partly to a lack of adequate technical knowledge, wells ran out of control, gas flared into the sky, oil ran over the country-side, and an oversupply of oil resulted. The situation worsened because a large number of producers did not have access to the market. But, rather than see their oil drained, they either ran it across the countryside or attempted to store it in highly inadequate makeshift storage facilities. The loss through seepage, evaporation, and fire ran into millions of barrels. ${ }^{22}$ The oversupply caused a depression of prices which threw the oil industry into economic chaos, and the whole economy suffered as a result. But this was not the only economic waste. The cost of producing oil under such a system was fantastic because of the number of wells drilled, the physical waste, and the premature abandonment of wells. The situation cried out for some form of regulation. The institution in Alberta of the M.P.R. restriction was purposely designed, at least as far as physical waste is concerned, to provide the necessary relief.

Once one has an M.P.R. restriction, is it necessary to go further and restrict production to market demand in order to further conservation?

17 Smith. The Commerce Power in Canada and the United States, 204 (1964).

18 See Zimmerman, Conservation in the Production of Petroleum, chap. 2.

10 The concept of economic waste is a far-reaching one including any type of pecuniary loss. Therefore, physical waste itself is economic waste, as pointed out by Hardwicke, in Market Demand as a Factor in the Conservation of Oil, 1st Ann. Inst. on Oil and Gas Law and Taxation. 149 (1949). Usually it is meant to refer to the economic losses suffered because of price instability, misallocation of resources, unemployment, etc.

20 Spooner Oils Ltd. v. Turner Valley Gas Conservation Board, [1933] S.C.R. 629, [1933] 3 W.W.R. 477.

$\because$ Zimmermna, ante, n. 18.

22 Although these conditions were more prevalent in the United States, we in Alberta suffered the same experience. It is estimated that, from the date of discovery of the Turner Valley field in 1924 to 1931. 236 to 260 billion cubic feet of gas were wasted. See, D. P. Goodal, P.Eng., Deputy Chairman. The Pctroleum and Natural Gas Conservation Board. Province of Alberta. An Historical Sketch of Oil and Gas Conservation in Alberta, An Address Given Before the Oilfield Technical Society, 1957. 
Is restriction to market demand necessary, firstly, to prevent physical waste, and, secondly, to prevent economic waste? This has long been an extremely contentious issue, especially in the United States, where restriction to market demand has been derided as simply a device to fix prices $^{23}$ and reduce competition in the interest of the oil industry. Some writers $^{24}$ in the United States suggest that limiting production to market demand is essential to prevent, not only economic waste, but also physical waste, both surface and underground. Because supply is adjusted to demand, prices do not fluctuate to any great extent; and, at any rate, are never so violently depressed as to precipitate the economic instability characteristic of the early 1930's. As a consequence, marginal wells are not prematurely abandoned, which permits a greater ultimate recovery. Were such wells abandoned, the cost of drilling and completion would be for naught; and would constitute economic waste in the sense that these expenditures could be diverted to some other part of the economy.

Zimmerman points out that not enough attention is paid to the underground waste which is prevented by a restriction to market demand. He suggests that without such a restriction only those producers who have access to the market would be producing. ${ }^{25}$ Since the M.E.R. is calculated on the basis of all the wells in the pool operating, such spotty production would cause an inefficient use of reservoir energy and would reduce total ultimate recovery. Surface waste, he argues, would also be caused, in that some of the producers who do not have access to the market would attempt to store their oil, causing loss through inadequate storage facilities, and possibly fire. Other authorities on oil and gas conservation agree with this proposition and state that restriction to market demand is essenial to prevent actual physical waste.

There is no reason to suppose that the results in Alberta would be any different from those in the United States. However, although physical waste is in effect avoided, is this the real purpose of the restriction to market demand; or is it just an incidental factor, the real purpose of the legislation being to regulate the production of inter-provincial oil? It may be helpful to examine the United States' constitutional position, which is strikingly similar to our own.

\section{The Position in the United States}

In the United States, Congress, by Article 1, section $8(3)$ of the Constitution, has been granted authority over inter-state commerce. That power has suffered the same ups and downs as the commerce clause in our constitution. However, American constitutional lawyers make it abundantly clear that Congressional power over inter-state commerce

23 Rostow is particularly adamant on this point: see Rostow, A National Policy for the Oil Industry. Other, more convincing authorities sugsest that this view is based on an insufficient understanding of the technolosy involved. See Zimmerman, ante, n. 18; Hardwicke, ante, n. 19; but compare Cassidy, Price Marketing and Price Behaviour in the Petroleum Industry, p. 113, n. 11.

24 Zimmerman, ante $n$. 18, at 318. Zimmerman cites other leading authorities on oll and gas conservation who support this view. The writer has not had access to these books. They are: H. B. Fell, Relation Between Market Demand and Physical Waste, 16-17; the same writer's contribution to Oil for Today. . . and for Tomorrow, 59-69 entitied "Excess Oll Production Causes Waste": Hines $\mathrm{H}$. Baker. Achievements and Unsolved "Excess Oil Production Causes Waste": Hines H. Baker, Achievements and Unsolved American Institute of Mining and Metaliurgical Engineers. Hardwicke gives a very good account of the problem: see ante n. 19 .

2.5 Zimmerman, id. at $315 \mathrm{ff}$. 
has now become so extensive that there are very few operations within the oil industry that it would not encompass. ${ }^{23}$ As has the Canadian Parliament, however, Congress has been content, to a large extent, to leave the regulation of the oil industry in the hands of the individual states.

The fundamental rule for determining the respective powers of Congress and of state legislatures is that enunciated in Cooley v. The Board of Wardens, ${ }^{27}$ and known as the Cooley doctrine. According to that doctrine, Congress has exclusive authority over inter-state commerce which is national in scope. Over inter-state commerce which is not national in scope, Congress and the state legislatures have concurrent powers, the Congressional power reigning paramount. As Professor Smith indicates, the inquiry is the same as it would be in the case of a double aspect test; for, in essence, the state is exercising its police power for a state purpose and in a state aspect. ${ }^{28}$ In view of these similarities, the treatment by the Supreme Court of the United States of pro-rationing schemes limiting production to market demand should be extremely helpful in the analysis of the Canadian legislation.

It seems clear that the state cannot legitimately legislate the prevent economic waste, for economic waste is a matter national in character. The true purpose and object of such legislation would be to regulate commerce-the restriction of supply to promote a stable price structure and hence a more economical use of resources. Both of these are matters concerning the economy as a whole; and, therefore, are national in scope. In view of this fact, in order for state pro-rationing legislation to be upheld, its real purpose must be shown to be the conservation of oil in a physical sense.

In the case of Champlin Refining Company v. Corporation Commission,"9 the Supreme Court of the United States held this to be the case. Mr. Justice Bulter, in delivering the opinion of the Court, reviewed the extensive technological evidence that had been submitted, and emphatically concluded that the limitation to market demand was necessary to prevent physical waste both above ground and underground, and that any effect on prices was merely incidental. The same result was reached by the Texas District Court in Amazon Petroleum Corporation v. Railroad Commission of Texas, ${ }^{30}$ in upholding the Texas pro-rationing scheme. ${ }^{31}$

Although these cases firmly established the authority of the state to pass pro-rationing measures, there is grave concern now prevailing in the United States that that power may be rendered ineffective. ${ }^{32}$ This concern has been precipitated by the recent decision of the United States Supreme Court in Northern National Gas v. Kansas. ${ }^{33}$ It was there held that a rateable take order, issued by the Kansas Corporation Commission and

26 David T. Searls, Present Status of Federal and State Jurisdiction in Connection with Regulation of, Exploration for, and Conservation. Production, and Sale of Oil and Gas (1964), 15th Ann. Inst. on OIl and Gas Law and Taxation 1.

27 (1852), 12 How. 299.

28 Smith. The Commerce Power in Canada and the United States 219 (1964).

29 (1932), 286 U.S. 210.

30 (1934), 5 Fed. Supp. 633.

31 See, also, Danciger Oil \& Refining Co. v. Railroad Commission. 49 S.W. (2nd) 837, which contains a good analysis of the problem.

:2 See, Granville Dutton. The Supreme Court's National Gas Act: Northern National Gas Co. v. Kansas, Completes Judicial Legislation, (1964), 2 Rocky Mountain Mineral Law Review 68.

::3 83 Sup. Ct. 645. 
requiring Northern to take a certain proportion of gas from various owners, was an invasion of the Federal Power Commission's authority to regulate comprehensively and effectively, pursuant to the Natural Gas Act, ${ }^{34}$ the transportation and sale of natural gas. It is contended that this decision, combined with the Supreme Court's decision in the equally famous Phillips ${ }^{35}$ case, where it was held that the Federal Power Commission's authority under the Natural Gas Act extended to the regulation of independent producers, could "effectively terminate the historical state control over oil and gas conservation," because "virtually every state conservation order-whether it applies to safe drilling practices, protection of fresh water, ... . production rules-indirectly affects the regulated price of natural gas." 36

For our purpose it should be remembered that, although these last two decisions may indirectly render ineffective prorationing schemes in the United States, they do not in any way purport to detract from the authority of the Champlin ${ }^{37}$ case to the effect that a restriction to market is necessary to prevent physical waste. Furthermore, in reference to the court's striking down of the rateable take order in the Northern case, ${ }^{38}$ it should be borne in mind that the occupied field doctrine was employed, a doctrine which has no counterpart in Canadian constitutional law..$^{39}$ The purport of the doctrine is that, once Congress has legitimately entered a particular field of regulation, its authority is so pervasive that it is taken to have pre-empted the whole field; and, therefore, even if there is no actual conflict or repugnancy between federal and state regulation, the state regulation cannot stand. ${ }^{40}$

\section{The Position in Alberta}

It is submitted that the Champlin ${ }^{41}$ and $A m a z o n^{42}$ decisions lend some support to the contention that the Alberta restriction to market demand is basically a conservation measure. The Oil and Gas Conservation Act, pursuant to which the measure was adopted, expressly states that its main purpose is the prevention of waste. ${ }^{43}$ It is true that it is the substance of the legislation, not the form, which is material; but, if it can be shown that the restriction does in fact enhance conservation, then certainly this is a major step towards illustrating that the intention of the legislation is truly expressed by the words of the Act.

34 (1939), 53 Stat. 821, as amended (1958), 15 U.S.C. $\S \S 717-717 \mathrm{w}$.

35 Phillips Petroleum Co. v. Wisconsin, 347 U.S. 672.

36 Ante, n. 33, at 71.

37 (1932), 286 U.S. 210.

38 Ante, n. 34 .

39 Laskin gives a thorough analysis of the doctrine's applicability in Canada in his article Occupying the Field: Paramountcy in Penal Legislation (1963), 41 Can. B. Rev. 235 . In concluding he indicates the circumstances in which the field may be said to be occupied concluding, he indicates the circumstances in which the field may be said to be occupled under Canadian constitutional principles. These restricted instances clearly illustrate that the

10 The writer has but cursorily treated the constitutional problem centered around the Natural Gas Act bceause it has no direct relevance to the problem at hand. Yet some mention-even if it is only to show that these cases have no direct bearing-is essential. For a fuller discussion, see Johnson. Producer Rate Regulation in Natural Gas CertificFor a Proceedings: in Contert (1962), 62 Colum L. Rev. 773; Acorn, The Background (1964), 3 Alta. L. Rev. 367, 384; D. E. Lewis, Provincial-Federal Co-operation (1964), 3 Alta. L. Rev. $412,415$.

11 Ante, n. 30.

42 Ante, $\mathrm{n}$. 31 . Act reads, in part: "The intent and purpose of this Act are: (a) To effect the conservation of the oil and gas resources of the province, (b) To prevent the waste of oll and gas resources in the province." $S$. $2(n)$ defines waste as "iv) the producing of oil and gas in excess of transportation or marketing facilities or of reasonable market demand." 
As in the United States cases, there is no reason why technological data could not be submitted to the Canadian courts to verify the legislature's purpose. In addition, the works of scholars on the subject of conservation could add to the province's position.

It is, therefore, suggested that there is a strong argument that the prorationing scheme, as it now exists, is in pith and substance in relation to conservation; and that the limitation of production to market demand is merely a necessary consequence and an incidental matter. If that is so, the double aspect test is satisfied.

It should be pointed out that, if a province tried to support the legislation on the basis that it prevents economic waste, it in all likelihood would not succeed. In admitting that the purpose of the legislation is to regulate the price of inter-provincial oil in order to prevent pecuniary losses and to add economic stability to the petroleum industry, it would be admitting that, in essence, it is regulating trade as such. Such an object is beyond the province's power, as the cases such as Lawson v. Interior Tree Fruit and Vegetable Committee of Direction, ${ }^{44}$ dealing with the marketing of natural products, clearly indicate.

\section{Equitable Distribution of Oil Producers}

If the conservation argument would not stand up, the province might still have a second string to its bow upon which to rely. It is suggested that a strong argument could be presented in favour of the view that the legislation is in pith and substance designed to ensure that the owners of minerals participate equitably in the oil produced from their land. As with conservation, equitable participation is declared to be one of the main objects of the Oil and Gas Conservation Act. ${ }^{45}$ Whether it is one of the main purposes of the legislation can best be determined by looking at what the consequences would be without it.

In Canada, there are many producers and few refineries. All but a very small percentage of these refineries are owned by companies which also conduct producing operations. It stands to reason that, if there were no pro-rationing in effect, the refineries. would purchase their oil from their own producers. This would be especially true in light of the fact that the producing operations are the more profitable. The direct result would be that a large number of producers in Alberta would find themselves without a market for their oil. In such a situation, there would seem to be two alternatives for producers without refineries, namely, either to produce and store the oil or else to cease production and have the oil drained by an integrated oil Company. In fact there is really no choice; for in Alberta it is necessary to get permission from the Oil and Gas Conservation Board in order to erect storage facilities, and it is unlikely that the Board would permit the storage of oil in circumstances in which there is no foreseeable market. But, more important, most of the producers, even if permitted to store their oil, would be in no position financially to do so. Therefore, in fact they would have to cease production and stand by to watch their oil drained.

44 [1934] S.C.R. 354.

$45 \mathrm{~S}$. $4(d)$ of the Act reads: "The intent and purpose of this act are: (d) to afford each owner the opportunity of obtaining his just and equitable share of the production of any pool." 
Of course, that conclusion is based on the assumption that without the restriction to market demand an oversupply of oil would still persist. History tends to verify this assumption; for, without such a restriction, supply in Alberta in 1949 began to exceed demand. ${ }^{40}$ At that time a number of producers, in order to avoid the consequences which it has been suggested would result, made representations to the Board requesting that an equitable system of pro-ration to market demand be established. The Board, after considering the several systems recommended, formulated the "Plan for Proration to Market Demand," which was put into operation in December, 1950. The basic principles of the scheme have remained intact to the present day.

Having regard to this history, it can be stated with some confidence that the true character and purpose of the pro-rationing scheme-its pith and substance-in addition to promoting conservation, is to provide an equitable basis for the distribution of oil among the owners of minerals within a pool. It is an implicit recognition that the owner of the minerals has an interest in the oil in place, and that it would be unfair that he should be deprived of the fruits of that interest because of financial disabilities. The legislature could just as easily have provided that the rule of capture has no place in the laws of Alberta. That the province could validly pass such legislation in relation to property rights there can be no doubt. It is clearly, within section 92 (13), "Property and Civil Rights." What is not so clear is whether the province can employ market demand as a basis for this equitable distribution. Does such use turn the purpose of the legislation into a regulation of trade and commerce, or is it simply an incidental matter?

It is submitted that there is some substance to the argument that the regulation of supply, and therefore of price, is an incidental matter. We must begin our analysis with the basic proposition that the legislature desires to give each owner a share of the production in the pool. How can this object be achieved by means other than compulsory unitization? Some practical standard must be set for dividing the production, in view of the fact that only a few of the producers would have access to the market.

That purpose could be achieved by making those who do produce account to the others in the pool for a certain percentage of the oil. Although the administrative difficulties, if this was left in the hands of the government, would be fantastic; they might, perhaps, be no greater than those now met in assigning to each well a production rate. Were such a scheme left in the hands of the producers, it would amount to compulsory unitization, which the legislature has not, as yet, seen fit to impose. At any rate, such schemes could not operate until the size of the pool had been ascertained.

Rather, the legislature has proceeded on the basis of allowing all wells to produce in order to obtain a fair share. How are they to determine how much should be produced? The easiest method is to determine the market demand, and then allocate so much to each well. It is, therefore, submitted that the restriction to market demand does not evidence an 
intention to regulate production as such, merely in order to maintain prices, the stability of the oil industry, and to fill the provincial coffers. On the contrary, this is just a practical method of distributing the oil equitably. The price regulation is, in truth, an incidental matter. Therefore, in addtion to the conservation argument, the province can also find some support in this latter argument.

\section{PROSPECTS IN THE SUPREME COURT OF CANADA}

What are the prospects of such agruments succeeding in the Supreme Court of Canada? It is submitted that they are excellent for two reasons. First of all, the oil industry has progressed very well, within the various provinces, through provincial regulation. The provincial legislatures have acquired a good deal of experience in this field, which Parliament could not, even if disposed to, acquire overnight. In other words, the provinces have demonstrated a high degree of efficiency in dealing with the oil industry's problem. Parliament is aware of this fact; and, consequently, has not attempted to assert its authority to any great extent in this area. It would be unrealistic to suggest that the members of the Supreme Court are not aware of these facts and would not be influenced by them. By finding a double aspect, they would present an easy solution to what is, in these days, a very difficult problem; for, in so doing, they would permit the provincial legislation to stand without denying authority to Parliament, should it ever choose to assert its authority. Even more significant is the fact that it is not very clear whether Parliament could claim jurisdiction over the oil industry, for the recent cases do not go so far as definitely to affirm that proposition. ${ }^{4 i}$ Therefore, if the provincial legislation were held invalid, we might find ourselves faced with a hiatus. ${ }^{48}$ The necessary consequence would be provincial-federal cooperation by means of delegation. ${ }^{40}$ It is true that the Supreme Court has found it necessary to take this position in other areas, such as the marketing of natural products; but, it is submitted, that was so because, on the facts, it was impossible to find that the province had confined itself to its legitimate provincial aspect. The provincial legislature in those cases had expressly purported to regulate inter-provincial trade, which was beyond its power. And even if it had not purported so to do, the legislation would have been struck down; for in a practical sense, because of the intermixing of local and intra-provincial trade, it would be impossible to regulate effectively one and not the other. Prorationing legislation does not present this problem; because the province can confine itself to its legitimate aspect, namely, conservation and the equitable sharings of oil in place.

17 Re The Farm Products Marketing Act, [1957] S.C.R. 198, certainly stopped short of giving Parliament such authority. It is significant that all of the judges who were in favour of allowing parliament greater power under the commerce clauses in that case are no longer sitting as members of the Court. The case of Regina v. Klassen (1959), 29 W.W.R. 369 (Man. C.A.), goes a long way to giving Parliament the required authority; but the approach taken there has yet to be passed on by the Supreme Court of Canada.

18 Theoretically, a hiatus should not arise because of the exhaustive distribution doctrine - l.e.. If the power does not lay with one of the legislatures it must, in a sovereign nation. lay with the other. But in practice, as the marketing cases have illustrated, theory will not provide a solution. It will not do so because of the inter-mixing of inter-provincial and intra-provincial trade. In a practical sense, it is impossible for one legislature to and intra-provincial trade. In a practical sense, it is impossible for one legislature to assert authority over the subject matter within its competence without asserting willing to give full scope to the necessarily incidental doctrine in order to resolve this difficulty in Parliament's favour: Lawson v. Interior Tree Fruit and Vegetable Committee of Direction, ante, n. 45; Re The Farm Products Marketing Act, ante, n. 48.

40 Such as in P.E.I. Potato Marketing Bd. v. H. B. Willis Inc., [1952] S.C.R. 392, [1952] 4 D.L.R. 146. 
The second reason why the Supreme Court of Canada might be disposed to find a double aspect lies in the fact that, in recent years, the Court has demonstrated a tendency to solve apparent federal-provincial clashes by calling in aid the double aspect doctrine. The Court, in so doing, has exhibited an extreme awareness of the tense political climate that now envelops us, and of the fact that in our increasingly complex society a great number of problems arise which can best be dealt with by the provincial legislatures. The finding of a double aspect in the field of criminal law best illustrates this tendency. Various provinces have passed statutory provisions dealing with drunken driving, ${ }^{, 0}$ careless driving, ${ }^{51}$ and failing to remain at the scene of an accident; ${ }^{52}$ and all have been upheld as having in pith and substance a provincial aspect and purpose. Similarly, provisions dealing with the fraudulent practices of security salesmen, ${ }^{53}$ with early closing hours, ${ }^{54}$ and with unconscionable transactions ${ }^{\text {in }}$ have been upheld by employing the double aspect test. All of these cases serve to indicate that the Supreme Court will hesitate to strike down provincial legislation if it can possibly find some legitimate provincial purpose which the legislation is designed to serve. Given this temper of the Court, it is submitted that there is a strong possibility of the Alberta pro-rationing scheme being upheld as legislation in relation to the conservation of oil and the equitable distribution of oil amongst the owners of minerals within a pool.

\section{NATURAL PRODUCTS MARKETING CASES}

To this point, the writer has refrained from discussing the cases on the marketing of natural products, because it is felt that they can be shortly disposed of. It has been suggested that the marketing cases offer a perfect analogy to the oil pro-rationing scheme; and, hence, are conclusive as to its invalidity. ${ }^{.6}$ Close scrutiny illustrates that, in fact, the analogy drawn is a false one.

In all of those cases in which the provincial marketing legislation has been struck down as being an invasion of the trade and commerce power, it was impossible for the court to find that the province had confined itself to its legitimate aspect. In each case the legislation very clearly spelled out that its purpose was to regulate the marketing of natural products. Because the facts indicated that most of the products were to be consumed outside the province, it was inevitable that the legislation should be characterized as a regulation of inter-provincial trade. What other possible characterization was open to the court? The same, however, is not true in respect of the prorationing scheme.

It is true that the scheme regulates the production of oil the greater percentage of which is destined for consumers outside the province; and it is true that if, like in the marketing cases, its only object were to

so Home Insurance Co. v. Lindal \& Beattie, [1934] S.C.R. 33.

51 Yolles v. The Queen (1959), 19 D.L.R. (2d) 19, approved in O'Grady v. Sparling. [1960] S.C.R. 804 .

62 Stephens v. The Queen (1961), 25 D.L.R. (2d) 296 (S.C.C.); O'Grady v. Sparling, [1960] S.C.R. 804, 25 D.L.R. (2d) 145 .

53 Smith v. The Queen, (1960] S.C.R. 776; Duplain v. Cameron, [1961] S.C.R. 693.

54 Lieberman v. The Queen (1963), 41 D.L.R. 125.

s5 A-G. for Ontario v. Barfield Enterprises Ltd., [1963] S.C.R. 570, 42 D.L.R. (2d) 137.

so Ballem, Constitutional Validity of Provincial Oil and Gas Legislation (1963), 41 Can. B. Rev. 199, 212.

si Lawson v. Interior Tree Fruit and Vegetable Committee, [1931] S.C.R. 357; Re Sheep and Swine Marketing Scheme, [1941] 3 D.L.R. 569; In re The Grain Marketing Act, [1931] 2 W.W.R. 146 (Sask. C.A.). 
regulate such production, it would be an invasion of the trade and commerce power. But, as has been indicated, that is not its real purpose. The provincial legislature is not concerned with the regulation of production as such; rather, its true purpose is to promote conservation and the equitable distribution of the oil. This is clearly a provincial aspect which the Supreme Court of Canada could legitimately seize upon. It is, therefore, submitted that the marketing cases so strongly relied upon do not offer any real assistance; and, at any rate, certainly are not decisive.

\section{UNITIZATION}

In view of the number of unitized operations in Alberta, is it necessary to limit production to market demand? It may be argued that it is unnecessary, because unitization ensures each owner of minerals within the pool a fair share of the production and is also the ideal of conservation operations. This is a sound argument; for, although it would mean that the integrated companies would only purchase from those units in which they had the largest interests, still, the owners in that unit would get an equitable share, and efficient conservation production would result. The fact that other units would not be producing would be no justification for the province to intervene, for nobody's oil is being drained and there is no waste of oil. If the legislature did intervene, the legislation would clearly be an attempt to provide all producers with a market for their oil; and would be, to that extent, an encroachment on the trade and commerce power. But, at present, not all pools in Alberta are unitized. Until the day when they are, the province still has legitimate interests to protect. For the reasons outlined in this paper, it is submitted that, as long as the legislation is designed to promote those interests, it is consitutionally valid. Of course, if the situation should ever reach a point where, say, a very large percentage of the pools were unitized, any argument that restriction of production to market demand was basically a conservation measure and a practical method of distributing production would necessarily flounder. ${ }^{5 s}$ In those circumstances, the legislature would have to resort to forced unitization to arrive at its desired objectives.

\section{CONCLUSION}

In conclusion, it can be stated with a fair degree of confidence that the pro-rationing scheme in Alberta would be upheld as legislation in relation to conservation and the equitable sharing of oil production among producers. In the event that this is an unwarranted conclusion, it would seem that the province may still enjoy a dominating position as owner of the greater percentage of the mineral rights in Alberta. ${ }^{59}$ However, it is unlikely that the legislation, at least in the near future, will be contested. The oil industry itself certainly is not prepared to take that step. In any event, the purpose of this paper has been served if it has done no more than indicate that the constitutionality of the pro-rationing scheme is not such an opened and shut issue as it has sometimes been made out to be.

58 It may be that this point has already been reached, for there certainly is today a high percentage of unitized operations in Alberta.

59 Provincialists always like to feel that, if worse comes to worst. the province can resort to its powers as property owners in order to regulate the oll industry. On its face there seems to be a lot to be said for this argument, but it is beyond the scope of this paper to $\mathrm{gO}$ into the detailed analysis which is required. 